\title{
Pinpointing the sources and measuring the lengths of the principal rivers of the world
}

\author{
S. Liu , P. Lu , D. Liu , P. Jin \& W. Wang
}

To cite this article: S. Liu , P. Lu , D. Liu , P. Jin \& W. Wang (2009) Pinpointing the sources and measuring the lengths of the principal rivers of the world, International Journal of Digital Earth, 2:1, 80-87, DOI: 10.1080/17538940902746082

To link to this article: http://dx.doi.org/10.1080/17538940902746082

曲 Published online: 17 Mar 2009.

Submit your article to this journal

Џll Article views: 119

Q View related articles $\circlearrowright$

4 Citing articles: 4 View citing articles ๘ 


\title{
Pinpointing the sources and measuring the lengths of the principal rivers of the world
}

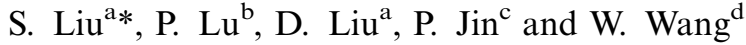 \\ ${ }^{a}$ Institute of Remote Sensing Applications, Chinese Academy of Sciences, Datun Road, \\ Chaoyang District, Beijing 100101, China; ${ }^{b}$ China Association for Science and Technology, 86 \\ Southern Colleges Road, Haidian District, Beijing 100081, China; ${ }^{C}$ China Aero-Geophysical \\ Survey \& Remote Sensing Centre for Land and Resources, 31 Colleges Road, Haidian District, \\ Beijing 100083, China; 'School of Environment and Nature Resources, Renmin University of \\ China, 59 Zhongguancun Street, Beijing 100872, China
}

(Received 10 November 2008; final version received 5 January 2009)

\begin{abstract}
Cultures throughout the world are associating with the rivers. People depend upon the rivers and their tributaries for food, water, transport, and many other aspects of their daily lives. Unfortunately, human beings have not calculated the accurate lengths for the great rivers even today. The lengths of the rivers are very different in popular textbooks, magazines, atlases and encyclopedias, etc. To accurately determine the lengths of the principal rivers of the world, the combination of satellite image analysis and field investigations to the source regions is proposed in this paper. The lengths of the Nile, Amazon, Yangtze, Mississippi, Yellow, Ob, Yenisey, Amur, Congo and Mekong, with lengths over or close to $5000 \mathrm{~km}$, were calculated using the proposed method. The results may represent the most reliable and accurate lengths of the principal rivers of the world that are currently achievable.
\end{abstract}

Keywords: principal rivers of the world; sources pinpointing; lengths measuring; satellite remote sensing; field explorations

\section{Introduction}

In 1852, human beings made the first attempt to measure the height of the highest summit of the world Qumolongma (also known as Everest). Thereafter, geodesists carried out several geodetic campaigns to determine the Qumolongma's accurate height with cutting-edge instruments and announced their measured results on several occasions. Chinese scientists have made six attempts to determine the accurate height of the Qumolongma since the Chinese alpinists conquered it in 1965 (Chen et al. 2001, Chen et al. 2006). Human beings began to explore the source of the Nile and measured the height of the Qumolongma almost at the same time. The longest river in the world, the Nile or the Amazon, has remained a mystery although Sir Richard F. Burton and John Hanning Speke began their exploration on the source of the Nile in 1856 (Ondaatje 1998).

Since the last century, the lengths of the Nile and Amazon have been contesting for the title of the world's longest river. From the lengths recorded in encyclopedias,

*Corresponding author. Email: liusc@irsa.ac.cn 
textbooks, magazines and atlases with various languages, one could not recognise the longest river in the world. The Nile in Africa is reported to be anywhere from $5499 \mathrm{~km}$ to $6695 \mathrm{~km}$ with a maximum difference of $1196 \mathrm{~km}$. And the Amazon in South America from $6275 \mathrm{~km}$ to $7025 \mathrm{~km}$ with a maximum difference of $750 \mathrm{~km}$. These significant inconsistencies could be found in other great rivers, e.g. the Yangtze from $5550 \mathrm{~km}$ to $6397 \mathrm{~km}$, the Mississippi from $5970 \mathrm{~km}$ to $6415 \mathrm{~km}$, etc. (Hanks et al. 1979, Arthur et al. 1980, Rand McNally Encyclopaedia of World Rivers 1980, The Encyclopaedia of American (International Edition) 1980, McWillam 1995, National Geographic Society 2000, National Geographic World Atlas for Young Explorers 1998, O’Neill and Yamashita 1993, Osborne, Peissel 1997, Ondaatje 1998), The New Encyclopaedia Britannica (15th Edition) 1980, William and Levey (eds) 1975, Winchester 2000). It is impossible to distinguish which is correct (or more accurate) in a series of controversial lengths for each river. Therefore, recalculation of the lengths with high accuracy using modern technologies is highly desirable.

The calculated length of one river depends on the position of the geographical source and the mouth, the data sources of the measuring based on and length measuring techniques. Locating the mouth of a river is pretty straightforward. It is normally defined as the intersection of the tangential line of two sides of the outlet and the middle line of the river. Searching the sources in the most inaccessible region on the Earth is an important event in the field of geography and has intrigued explorers for centuries. At present, pinpointing the sources of the great rivers can still arouse the interest of explorers around the world. As the Chinese saying goes, "When one drinks water, one should think of the source". This Chinese proverb describes the explorers' motivations for discovering the source of the great rivers. Most of the sources of the great rivers have been determined by different explorers according to various criteria in the past. In our investigations, the source of the river is defined as the spring corresponding to the longest branch in the drainage basin from which water runs all year round. It is believed that this definition of the geographical source is reasonable because the length of the river is more stable than the amount of water flow, the latter with annual, seasonal and even daily change. Furthermore, the length of one river defined as the length from the mouth at the sea to the spring farthest from the sea tallies with the human beings' convention.

The common data sources for measuring the lengths of the rivers are the topographic maps with adequate scale. However, the large-scale topographic maps are classified information to many countries and are not available for purchase from market sources. In addition, for some regions of the rivers' traversed, the large scale topographic maps are not readily available although the small- or medium-scale maps can be obtained from atlases in different languages. It is well-known that the measured length of a river depends on the scale of the map on which the measurement is based on; in general, due to the fractal quality of a river, the smaller the scale, the shorter the resulting length measurement. This is because some details of the river's channels are generalised according to various mapping specifications. This is the reason for large variation in the lengths of the principal rivers in various literatures.

In addition, the length measuring techniques also influence the accuracy of measured length of the rivers. Many decades ago, geographers and cartographers measured the lengths of the rivers on the topographic maps with special metric scales that could determine the length of curves, or using digitising tablets after the 
appearance of computers. The geographers and cartographers obtained more precise lengths with computer and digitising tablets than with the use of metric scales. However, the accuracy of the length by both methods is inferior compared with the geographical information system (GIS) and/or remote sensing software that have been widely used by modern geoscientists. Nevertheless, most of the data of the principal rivers still prevail in encyclopedias, textbooks, magazines and atlases although computers have appeared.

Based on the maps with inadequate scale and/or incomplete data sources, inaccurate length measuring techniques and controversial starting points, it is not surprising that people could not get reliable and accurate lengths for the principal rivers of the world.

\section{Methodology}

Remote sensing imagery is capable of covering large areas with quantitative observational parameters such as spectral radiance (Rencz 1998, Sabins 1996, Schowengerdt 1997, Wang 1990). It is therefore a potentially rich data source for locating the sources and calculating the length of the rivers. Governments and commercial agencies of many countries support a series of satellites for long-term global observations of the land surface, biosphere, solid Earth, atmosphere and oceans. Although there are many remote sensing satellite series in operations, such as IKONOS, QuickBird, SPOT, ERS, RADARSAT, IRS, CBERS, LANDSAT and others, not all is suitable for measuring the length of rivers on the Earth. The images are selected on the basis of converges, resolution, availability and cost. Among all the remote sensing satellites, Landsat series satellite data are the only record of global land-surface conditions at the scale of tenths of meters over the last 30 years. Data at these spatial resolutions can provide acceptable accuracy in measuring the rivers and are also available in the market. In this paper, the Landsat TM and ETM + image are chosen as the data source for measuring the length of the principal rivers of the world.

Satellite image rectification was made for all images used in this study. For measuring the exact lengths of the principal rivers of the world, it is necessary to choose one coordinate and projection system that is suitable for high-accuracy application. NASA has sponsored the creation of an orthorectified and geodetically accurate global data set of Landsat MSS, TM and ETM + to support a variety of scientific studies and educational purpose (Tucker 2004). These images are precision orthorectified Landsat scenes delivered in the standard Landsat individual scene coverage (approximately $180 \mathrm{~km} \times 180 \mathrm{~km}$ ) and are available for the whole globe in either the two epochs of circa 2000 or earlier base-line coverage of circa 1990. In this project, orthorectified Landsat ETM + scenes of circa 2000 are selected as the main data source for measuring the length of the rivers. Precision orthorectified Landsat ETM + scenes were acquired from 1999 to 2002 with a spatial pixel resolution of $14.25,28.5$, and 57.0 meters for the panchromatic, reflective and thermal bands respectively. Nearest neighbour resampling method was used in the orthorectification. These data sets are comprised of all nine Landsat ETM + spectral bands and are in a UTM (Universal Transverse Mercator) map projection and WGS-84 coordinate system with a geodetic accuracy of better than 50 meters RMSE (Root Means Square Error). For some regions that ETM+images are not available, the 
orthorectified Landsat TM images acquired in circa 1990 are used. Landsat ETM + and TM bands are generally made into colour images for the interpretation purpose. In principle, any three of the visible and reflected IR bands may be combined in blue, green and red channels to produce a colour image. Band assignments are often expressed in R, G and B order. For example, the assignment 4, 2, 1 means that band 4 was assigned to red, band 2 to green and band one to blue. There are over one hundred possible colour combinations, which is an excessive number for practical use. Theory and experience show that a small number of colour combinations are suitable for most applications. The optimum band combination is determined by terrain, climate and nature of the interpretation projects. In this project, the water has the spectral characteristics significantly different from the other objects of the Earth surfaces and is very easily recognised by the interpreters. The band assignment is $5(\mathrm{R}), 4(\mathrm{G}), 3(\mathrm{~B})$ for all the scenes of the Landsat scenes.

The length was measured along the central line of the river's mainstream, from its geographical source to the mouth. Prior to or during measurement, the channels can be recognised from images by processing the satellite images, e.g. contrast enhancement, intensity, hue and saturation transformation, filtering of random noise, atmospheric correction and others. Based on the orthorectified satellite images mentioned above, the measured length of river with accuracy between 3:1000 and 5:1000 of the length can be achieved.

To verify if the springs with water run year-around, late autumn is the ideal season for field explorations to the source region especially for the rivers with sources far away from the equator. In winter, the water is frozen or the channels are covered with snow. In spring the snow and ice is melting. Summer is rainy and the channels in river source region will be filled with water. In late autumn, the rainy season passed and winter is not coming. If water is flowing in the creeks in late autumn, we are sure the springs with water run year-around. We have investigated the source of Mekong in 1999 and 2002, Yangtze in 2000, Ob-Irtysh in 2003, Yellow, Amur, Yenisey and Mississippi-Missouri in 2004 and Amazon, Nile and Congo in 2005. The distribution of the sources of the investigated rivers on the global has been shown in Figure 1.

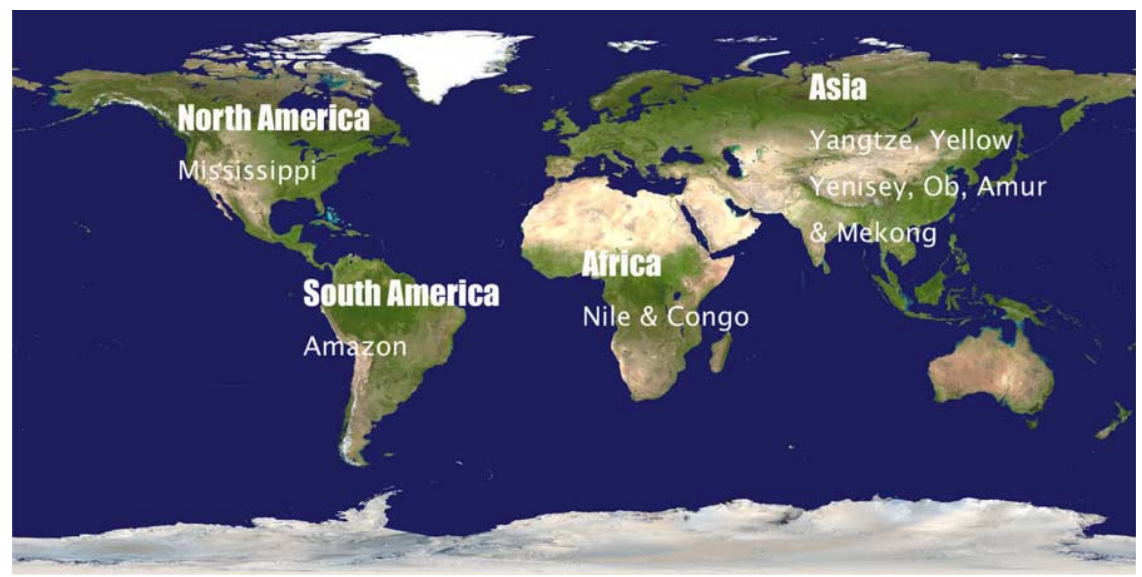

Figure 1. Global distribution of the sources of the principal rivers. 
Table 1. The lengths, geographic sources and the outflow of the top 10 longest rivers of the world.

\begin{tabular}{|c|c|c|c|}
\hline River & $\begin{array}{l}\text { Geographic position } \\
\text { of the source }\end{array}$ & Outflow & Length $(\mathrm{km})$ \\
\hline Nile & $\begin{array}{l}\text { Long. } 29^{\circ} 21^{\prime} 30^{\prime \prime} \mathrm{E} \\
\text { Lat. } 2^{\circ} 19^{\prime} 35^{\prime \prime} \mathrm{S} \\
\text { Elev. } 2539 \mathrm{~m} \\
\text { Nyungwe National Park, } \\
\text { Rwanda }\end{array}$ & $\begin{array}{l}\text { Mediterranean } \\
\text { Sea }\end{array}$ & 7088 \\
\hline Amazon & $\begin{array}{l}\text { Long. } 71^{\circ} 41^{\prime} 36^{\prime \prime} \mathrm{W} \\
\text { Lat. } 15^{\circ} 30^{\prime} 13^{\prime \prime} \\
\text { Elev. } 5189 \mathrm{~m} \\
\text { Mt. Nevado Mismi, } \\
\text { Peru }\end{array}$ & Atlantic Ocean & 6575 \\
\hline Yangtze (Changjiang) & $\begin{array}{l}\text { Long. } 94^{\circ} 35^{\prime} 54^{\prime \prime} \mathrm{E} \\
\text { Lat. } 32^{\circ} 43^{\prime} 54^{\prime \prime} \mathrm{N} \\
\text { Elev. } 5042 \mathrm{~m} \\
\text { Mt. Tangula, Qinghai, China }\end{array}$ & Pacific Ocean & 6236 \\
\hline Mississippi-Missouri & $\begin{array}{l}\text { Long. } 111^{\circ} 32^{\prime} 54^{\prime \prime} \mathrm{W} \\
\text { Lat. } 44^{\circ} 32^{\prime} 18^{\prime \prime} \mathrm{N} \\
\text { Elev. } 2692 \mathrm{~m} \\
\text { Hell Roaring Creek, Idaho USA }\end{array}$ & Gulf of Mexico & 6084 \\
\hline Yenisy & $\begin{array}{l}\text { Long. } 97^{\circ} 58^{\prime} 25^{\prime \prime} \mathrm{E} \\
\text { Lat. } 47^{\circ} 54^{\prime} 38^{\prime \prime} \mathrm{N} \\
\text { Elev. } 2711 \mathrm{~m} \\
\text { West of Mongolia }\end{array}$ & Arctic Ocean & 5816 \\
\hline Yellow (Huanghe) & $\begin{array}{l}\text { Long. } 96^{\circ} 20^{\prime} 23^{\prime \prime} \mathrm{E} \\
\text { Lat. } 34^{\circ} 29^{\prime} 37^{\prime \prime} \mathrm{N} \\
\text { Elev. } 4852 \mathrm{~m} \\
\text { Lalangqing Qu, Qinghai, China }\end{array}$ & Gulf of Bohai & 5778 \\
\hline Ob-Irtysh & $\begin{array}{l}\text { Long. } 89^{\circ} 58^{\prime} 17^{\prime \prime} \mathrm{E} \\
\text { Lat. } 47^{\circ} 52^{\prime} 32^{\prime \prime} \mathrm{N} \\
\text { Elev. } 2916 \mathrm{~m} \\
\text { Mt. Mangdaiqia, } \\
\text { Xinjiang, China }\end{array}$ & Gulf of $\mathrm{Ob}$ & 5525 \\
\hline Amur (Heilongjiang) & $\begin{array}{l}\text { Long. } 109^{\circ} 10^{\prime} 30^{\prime \prime} \mathrm{E} \\
\text { Lat. } 48^{\circ} 47^{\prime} 07^{\prime \prime} \mathrm{N} \\
\text { Elev. } 2016 \mathrm{~m} \\
\text { East of Mongolia }\end{array}$ & Tatar Strait & 5498 \\
\hline Congo (Zaire) & $\begin{array}{l}\text { Long. } 31^{\circ} 07^{\prime} 58^{\prime \prime} \mathrm{E} \\
\text { Lat. } 9^{\circ} 22^{\prime} 04^{\prime \prime} \mathrm{S} \\
\text { Elev. } 1580 \mathrm{~m} \\
\text { East of Zambia }\end{array}$ & Atlantic Ocean & 5118 \\
\hline $\begin{array}{l}\text { Mekong } \\
\quad \text { (Lancangjiang) }\end{array}$ & $\begin{array}{l}\text { Long. } 94^{\circ} 40^{\prime} 52^{\prime \prime} \mathrm{E} \\
\text { Lat. } 33^{\circ} 45^{\prime} 48^{\prime \prime} \mathrm{N} \\
\text { Elev. } 5200 \mathrm{~m} \\
\text { Mt. Jifu, Qinghai, China }\end{array}$ & South China Sea & 4909 \\
\hline
\end{tabular}


By the interpretation of the satellite images with adequate resolutions, the longest branch in drainage basin can be identified in sources regions. One river may have several potential sources. The objective of field investigation is to visit all the potential sources and find out the one fit all the criteria for the geographic source. The precise positions of the geographical sources were checked with GPS (global positioning system) in field explorations. Hand-held GPS provides the position of the geographic source with an accuracy of 10 to $20 \mathrm{~m}$. The geographic positions of the sources of the principal rivers with their calculated lengths are listed in Table 1.

\section{Results and conclusions}

In 1999, we have the first attempt to measure the lengths of the principal rivers of the world. Up to now, we have completed the length measuring and sources' region explorations for 10 rivers with lengths over or close to $5000 \mathrm{~km}$. The calculated lengths of the top 10 rivers are the Nile $7088 \mathrm{~km}$ (4405 miles), Amazon $6575 \mathrm{~km}$ (4086 miles), Yangtze $6236 \mathrm{~km}$ (3876 miles), Mississippi $6084 \mathrm{~km}$ (3781 miles), Yenisey $5816 \mathrm{~km}$ (3615 miles), Yellow $5778 \mathrm{~km} \quad$ (3591 miles), Ob $5525 \mathrm{~km}$ (3434 miles), Amur $5498 \mathrm{~km}$ (3417 miles), Congo $5118 \mathrm{~km}$ (3181 miles) and Mekong $4909 \mathrm{~km}$ (3051 miles). The lengths with the geographic positions of their sources are listed in Table I. The distribution of the geographic sources of the great rivers on the Earth can be found in Figure 1.

In the next stage, some rivers in the world which play an important economic, social, natural and cultural roles in the lives of more people will also be considered. We expect to report the new measuring results of those rivers in the near future.

\section{Acknowledgements}

The authors would like to thank the following people: Professor Guo Huadong, Professor Chen Shupeng, Professor Huang Binwei, Professor Wang Zhizhuo, Professor Li Deren, Professor Lin Zongjian, Professor Li Jiancheng, Dr. Wu Xiaoliang, Professor Qin Dahe, Professor Liu Xiaohan, Professor Li Xiaowen, Professor Tong Qingxi, Professor Niu Zheng, Mr Guo Shan, Professor Wu Yirong, Professor Xiang Maosheng, Professor Li Rongxing, Professor Di Kaichang, Mr. Xiawu Duojie, Mr Zheng Ming, Mr Ye Yan and Mr Fang Zhimin for their generosity assistances and encouragements. This work was jointly supported by China High-Tech Research and Development Project (863 Project), the Innovation Project of Chinese Academy of Sciences, the Special Funds of Director General of Institute of Remote Sensing Applications, Chinese Academy of Sciences, the Funds of the State Key Laboratory of Remote Sensing Sciences of China and the Funds of the State Key Laboratory of Information Engineering in Surveying, Mapping and Remote Sensing of China and Earth \& Space Awards of the Earth and Space Foundation.

\section{Notes on contributors}

Shaochuang Liu received a BS degree of Geodesy in 1985 and MS degree and PhD of Photogrammetry and Remote Sensing in 1991 and 1997 from Wuhan Technical University of Surveying and Mapping, China. He is a professor of Institute of Remote Sensing Applications, Chinese Academy of Sciences. His research interests include airborne integrated mapping system, lunar rover localisation, navigation and mapping technology and remote sensing of the Earth's polar region. 
Pingli Lu received her MS degree of Remote Sensing and GIS from China University of Geosciences in 2006. She is an engineer of the China Association for Science and Technology. Her research interests include image processing and spatial analysis.

Donghui Liu got a MS degree in Geography from Beijing University in 1997. He is an assistant professor of Institute of Remote Sensing Applications, Chinese Academy of Sciences. His research interests include images processing and GIS.

Peidong Jin is a principal research scientist of China Aero-Geophysical Survey \& Remote Sensing Centre for Land and Resources. He got his B.S degree from Changchun University of Science and Technology in 1985. He is specialising in the image processing and GIS.

Wen Wang received his PhD in Cartography and Geographical Information System from Institute of Remote Sensing Applications, Chinese Academy of Sciences in 1997. He is an associate professor of the School of Environment and Nature Resources, Renmin University of China. His research interests include geostatistics and remote sensing for agriculture.

\section{References}

Arthur, J. S., Green, R. J., Kinka, R. and Fernádez M. B. M., 1980. Webster's New Geographical Dictionary. Springfield, Massachusetts: G. \& C. Merriam.

Chen, J., Pang, S., Zhang, J., and Zhang, Q., 2001. The height determination of Qomolangma Peak in China: Review and analysis. Acta Geodatetica et Cartographica Sinica, 30, 1-5.

Chen, J., Yue, J., Guo, C., and Zhang, P., 2006. Progress in technology for the 2005 height determination of Qomolangma Feng (Mt. Everest). Science in China (Earth Sciences), 49 (5), 531-538.

Hanks, P., Long, T. H., and Urdang, L., 1979. Collins Dictionary of the English Language. London and Glasgow: William Collins Sons.

McWillam, F., 1995. Locating the Sources of the Mekong, The Geographical Magazine LXVII 5

National Geographic Society, 2000. http://news.nationalgeographic.com/news/2000/12/ 1221amazon.html

National Geographic World Atlas for Young Explorers, 1998. National Geographic Society, Washington, D.C.

Ondaatje, C., 1998. Journey to the source of the Nile. Toronto: Harper Collins Publishers.

O'Neill, T. and Yamashita, M. S., 1993. The Mekong: A haunted river's season of peace. National Geographic, 183 (2), 1-35.

Osborne, M., 1999. River road to China: the search for the sources of the Mekong 1866-73. New York: Atlantic Monthly Press.

Peissel, M., 1997. The last barbarians: the discovery of the source of the Mekong in Tibet. New York: Henry Holt \& Company.

Rand McNally, 1980. Encyclopaedia of world rivers. Chicago: Rand McNally.

Rencz, A. N. (ed), 1998. Remote sensing for earth sciences, manual of remote sensing. $3^{\text {rd }}$ ed. New York: Wiley.

Sabins, F., 1996. Remote sensing: principle and interpretation. New York: W.H. Freeman and Company.

Schowengerdt, R. A., 1997. Remote sensing: models and methods for image processing. San Diego, C.A: Academic Press.

The Encyclopaedia of American (International Edition), 1980. Danbury, Connecticut: Americana Corporation.

The New Encyclopaedia Britannica. 1980. 15th ed. Chicago/London/Toronto/Geneva/Sydney/ Tokyo/Manila/Seoul: Encyclopaedia Britannica Inc..

Tucker, C. J., 2004. NASA's Global Orthorectified Landsat Data Set. Photogrammetric Engineering \& Remote Sensing, 70, 313-322. 
Wang, Z., 1990. Principles of photogrammtry (with remote sensing). Beijing: Press of Wuhan Technical University of Surveying and Mapping \& Publishing House of Surveying and Mapping.

William, H. and Levey, J. S. (eds), 1975. The New Columbia Encyclopaedia. New York and London: Columbia University Press.

Winchester, S., 2000. Black Dragon River: On the edge of Empires. National Geographic, 197 (2), 1-33. 